\title{
A Multi-Objective Approach to Evaluate the Economic and Environmental Impacts of Alternative Water and Nutrient Management Strategies in Africa
}

\author{
M. Pastori, A. Udías, F. Bouraoui*, and G. Bidoglio \\ European Commission Joint Research Centre (JRC), Institute for Environment and Sustainability, Ispra I-21027, Italy
}

Received 16 December 2014; revised 20 April 2015; accepted 18 July 2015; published online 21 August 2015

\begin{abstract}
African agriculture is one of the less productive of the world because of low use of available water resources and of limited fertilizer input. A large increase in agricultural production is needed to meet increasing food requirements of the growing population of Africa, augmenting the risk of environmental pollution. In order to limit this risk adoption of sustainable irrigation and fertilization practices is required. The efficiency of these practices depends on numerous and conflicting objectives which lead to a complex multi-objective decision process. In this work we quantified the trade-offs among the agricultural gross margins and nitrates pollution for the major African crops. Based on an integrated biophysical model and a multi-objective evolutionary algorithm, we estimated optimal solutions (Pareto front) among both objectives to identify efficient irrigation and fertilization management patterns in several African countries. This analysis pointed out how the increase of farmer benefit is always related to a higher amount of nitrates losses. Knowledge of these sets of solutions helps decision-makers to choose optimum alternative strategies specifically tailored to each country. The multi-objective analysis indicates that in most of African countries farmers can significantly increase their income while preserving at the same time environment by adopting efficient fertilization and irrigation strategies.
\end{abstract}

Keywords: EPIC, trade-offs, multi-objective optimization, irrigation, fertilization, nitrate losses, environment, Africa

\section{Introduction}

African agriculture is one of the less productive of the world because of low use of available water resources and of limited fertilizer input (Fleshman, 2006). A large increase in agricultural production is needed to meet increasing food requirements of the growing population of Africa. According to FAO estimates (FAO, 2009a) a general increase of food production by $70 \%$ is expected between 2005 and 2050 and, African countries in particular will have almost to double their average crop production to meet these new needs. African agriculture has enormous potential for growth thanks to its natural resources including water and land, which in many cases are only partially used (Morris et al., 2009). African agriculture will need to invest capital and technology to adapt to the new situation, ensure a proper policy environment and provide adequate training to farmers in order to achieve higher crop yields and ultimately ensure food security (Rosegrant and Cline, 2003).

Recent research has shown that in most African countries, the main biophysical factor limiting crop production is nitro-

\footnotetext{
* Corresponding author. Tel.: +39033278 5173; fax: +39033278 5601.

E-mail address: faycal.bouraoui@jrc.ec.europa.eu (F. Bouraoui).
}

ISSN: 1726-2135 print/1684-8799 online

(C) 2017 ISEIS All rights reserved. doi: 10.3808/jei.201500313 gen while water scarcity (including precipitation and irrigation) is the main issue in a more restricted number of countries (Pastori et al., 2011). Producing more food is feasible in Africa, but it should not be done at the expenses of degrading the environment (The Montpellier Panel, 2013). Even in water rich regions, irrigation has to be managed properly through appropriate infrastructure and efficient technology in order to preserve water resources and to avoid large nutrient losses that may occur through bad practices. For example, increased water abstraction for irrigation could conflict with the demands of water for domestic or industrial use, leading also to adverse ecological effects (Bates et al., 2008). Some countries (mainly Northern Africa) are already mining and overexploitting water resources (Pastori et al., 2011), an issue destined to increase in the context of rising climate stresses including drier and hotter climate and increased variability of the water availability.

Negative impacts of intensive farming on water quality are already reported in several regions of Africa (Fianko et al., 2009; Maherry et al., 2008; Sall and Vanclooster, 2009; Fetouani et al., 2008). This degradation might continue in the near future since the most important increase in reactive nitrogen input over the next decades will occur in tropical African countries, regions that have already shown evidence of high $\mathrm{N}$ deposition and that are also an important reserve of biodiversity (Galloway et al., 2008).

Proposed alternatives to achieve higher yields are given 
by Easterling and Apps (2005). However an uncontrolled intensification could potentially increase adverse agriculture impacts on the environment and lead to new conflicts between different end-users (Schröter et al., 2005; IPCC, 2007). The regional identification of realistic and effective Best Management Practices (BMPs) contributes to a better policy-making procedure (Romero and Rehman, 2003; Gómez-Limón and Riesgo, 2004; Rizov, 2004; Arabatzis and Manos, 2005; Pujol et al., 2006; Manos et al., 2007, 2010, 2013) and minimizes the costs of implementation of the selected strategies while increasing their acceptability by the end-users (Bouraoui and Grizzetti, 2014). However, for a given region (country, basin, etc.) with different farm typologies, soils, climatic conditions and crops the possible number of potential and effective management practices can increase vastly, and finding the right balance between maximizing crop income, while limiting at the same time environmental (and social) impacts becomes a high complex task. A large number of BMPs are available for implementation from local to national scales. The selection of the optimal set of solutions requires a simultaneous optimization of two or more conflicting criteria.

Optimization algorithms have been widely used in environmental modelling (Reed et al., 2013; Jegannathan et al., 20 11; Recknagel, 2013; Nicklow et al., 2010) with an increase use of multi-objective approaches. In the case of multi-objective optimization problems, usually there is no unique optimal solution, but there is a set of solutions which are superior to the rest of solutions: these are known as Pareto-optimal or non-dominated solutions (Hans, 1988). This type of approach has great potential for addressing problems in managing conflicting objectives (Ines et al., 2006; Bryan and Crossman, 2008; Higgins et al., 2008; Sadeghi et al., 2009; Meyer et al., 2009; Whittaker et al., 2009; Latinopoulos, 2009). Several authors have combined the use of biophysical and multi-objective programming models (Fernandez-Santos et al., 1993; Rabotyagov et al., 2010; Panagopoulos et al., 2012; Panagopoulos et al., 2013). Pandey and Hardaker (1995) provide an overview of the usefulness of bio-economic modelling for studying the interaction between farm management practices and economic criteria to analyse sustainability of farming systems.

The overall goal of this paper is to apply a multi-objective evolutionary optimization which combines the biophysical farm model EPIC (Williams, 1995) and a multi objective optimization algorithm (Udías et al., 2011) to assess the effects of potential agricultural management practices in Africa. We evaluate two main potentially conflicting objecttives including the maximization of farmer's income and the minimization of the environmental impact using the nitrogen leaching loss as a proxy. The main outputs of the analysis are the identification and quantification of trade-off strategies (Pareto frontier curves) between these two potentially conflicting objecttives at country level for representative African countries.

The novelty of the study lays in the application of the multi-objective optimization approach at continental scale based on high resolution data (global studies resolution is often larger than $50 \mathrm{~km} \times 50 \mathrm{~km}$ ) providing a multi-scale tool for identifying at large scale hot spots of mismanagement, and providing at the regional scale detailed optimal sets of sustainnable water and fertilizer management strategies. Identified irrigation and fertilization Pareto strategies will help determine the opportunity costs of reducing nitrate pollution, and facilitate the choice of most appropriate management strategies according to stakeholders (farmers, citizens and environment) specific needs at the local and regional scales.

\section{Material and Method}

\subsection{Multi-objective Approach}

The aim of this work is to apply for the whole African continent a multi-objective optimization tool to identify tradeoff optimum strategies for agricultural land management between profit and environmental impacts in view of helping decision makers to select the optimal solutions according to specific needs and requirements including social, health, economic and environmental priorities. Indeed, decision analysis requires the choice of one alternative among others, a difficult process, especially if the alternatives are non-dominated for a given set of criteria. An alternative is dominant when it is the best solution by considering all decision criteria. Since the decision criteria considered in this study reflect both economic costs as well as environmental status, no single alternative will be dominant because of the potential conflicting nature of the two decision criteria: intensifying agriculture could lead to increase water depletion and degradation and endanger ecological health.

Our analysis is based on the combination of the biophysical model EPIC (Williams, 1995) with a multi-objective evolutionary algorithm (Udías et al., 2011). The model EPIC was chosen as it simulates crop production under different farming practices and operations including fertilization and irrigation application rates and timing, and since it considers nutrient losses to the environment. In addition, it has been thoroughly evaluated and applied from local to continental scale (Gassman et al., 2005) and used in global assessment (Liu et al., 2008; Liu et al., 2009; Pastori et al., 2011). The model has been applied for irrigation scheduling assessment (Rinaldi, 2001; Wriedt et al., 2009) and impact assessment of nutrient on crop yield production (Van der Velde et al., 2014). Finally the model has demonstrated good performance in simulating actual yields in most of the African countries for different crops and agricultural environments (Pastori et al., 2011; Folberth et al., 2012).

A flowchart of the methodological framework is displayed in Figure 1. The agricultural management strategies considered in the optimization process are linked to crop fertilization and irrigation schemes (total amount and scheduling). They are the most important factors controlling yield gaps (difference between current and attainable yields for a given region) which are generally very high in several African regions (Mueller et al., 2012). The optimization approach requires the following steps: a) define the set of agriculture management options and their range of variability, b) select 


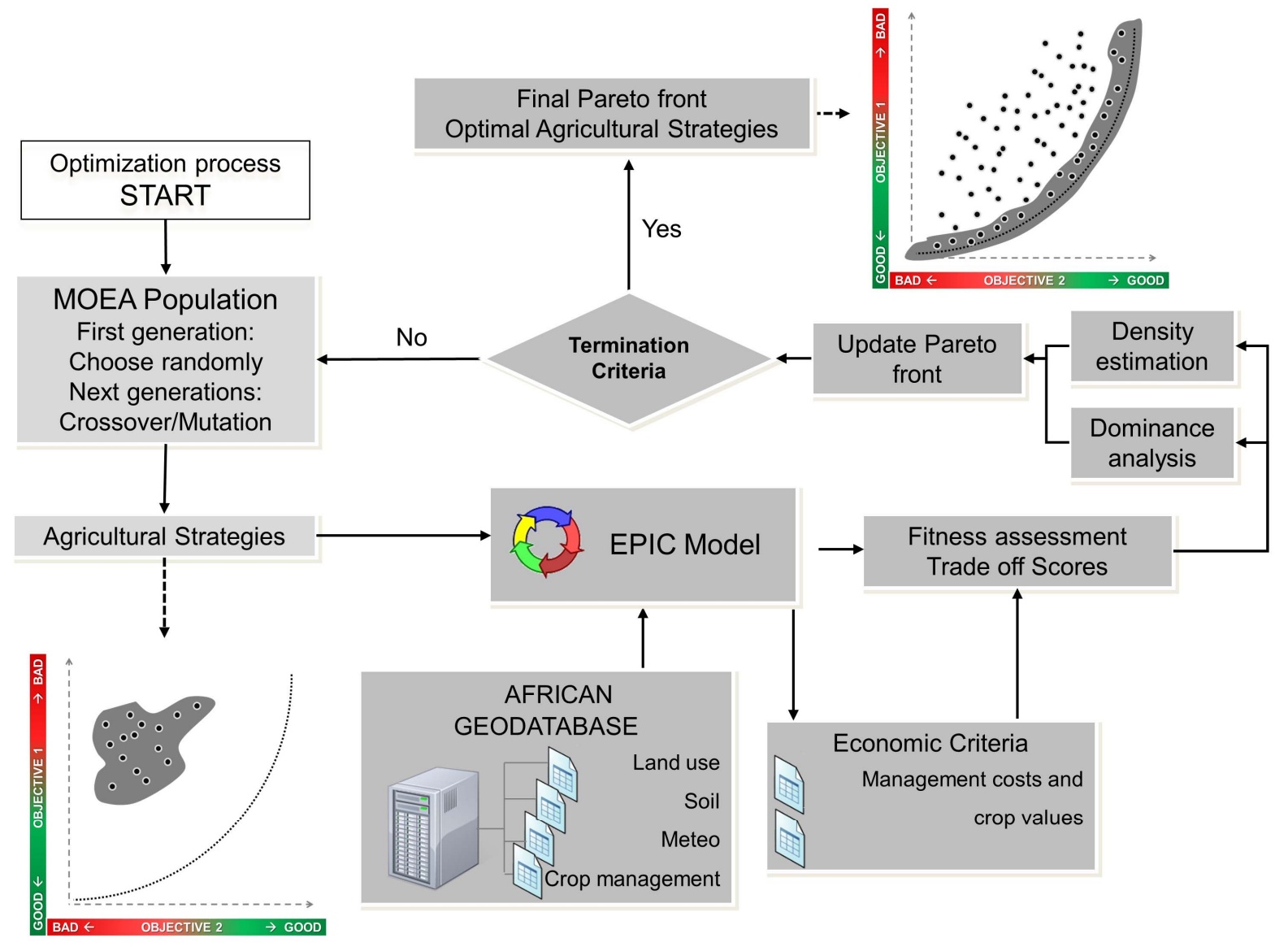

Figure 1. Flow chart of the integrated MOEA-EPIC-GIS methodology.

major crops in each country, c) collect information about market price of crops, and cost of water and fertilizer in each country, d) define the area (countries) where to perform the analysis, e) specify the objective functions for the optimization algorithm.

\subsection{The EPIC Biophysical Model}

EPIC is a biophysical, continuous, field scale agriculture management model. It simulates crop water requirements and the fate of nutrients and pesticides as affected by farm management activities such as the timing of agrochemicals application, tillage, crop rotation, irrigation strategies, etc. The main components can be divided in the following items: hydrology, weather, erosion, nutrients, and plant growth. The model estimates crop development on a daily time-step based on light interception and conversion of $\mathrm{CO}_{2}$ to biomass. The crop phenological development is based on daily heat units accumulation. Root growth is limited by temperature stress, soil strength, and aluminum toxicity whereas above ground biomass growth is constrained by water, nutrient ( $\mathrm{N}$ and $\mathrm{P})$, temperature, and aeration stress. Water and nutrient stresses are based on deficits compared to the optimal supply on each day. Crop yield is calculated via harvest index as a fraction of aboveground biomass. The hydrological model is based on the water balance equation in the soil profile where the processes simulated include surface runoff and infiltration, evapotranspiration, lateral subsurface flow, and percolation. EPIC takes into account nitrogen and phosphorus cycles (mineralization, denitrification, volatilization, fixation processes). Nitrate losses are related to the processes of leaching, runoff and lateral subsurface and are calculated as a function of flow volumes and nitrate average water concentration. For a detailed and complete description of the model and the simulated processes see Williams (1995).

\subsection{Input Data}

A geo-database was developed to support the application of EPIC for the whole African continent. It includes all data required by EPIC (meteorological daily data, soil data, land use data with crop distribution, and agriculture management information) to simulate different agronomic management strategies.

The Harmonized World Soil Database (HWSD) (FAO et al., 2012) with a resolution of about $1 \mathrm{~km}$ (30 arc second) was 
used to characterize the soils of the simulation units. A global digital elevation model (DEM) with a horizontal grid spacing of 30 arc seconds (FAO, 2009b) was processed to obtain the mean elevation and slope within each unit. The global crop dataset SAGE (Monfreda et al., 2008) was selected to derive a complete land use dataset for all countries. SAGE dataset is a detailed database of global land use describing the area (harvested) and yield of 175 distinct crops for the year 2000 on a $5 \mathrm{~min}$ by $5 \mathrm{~min}$ (approximately $10 \mathrm{~km} \times 10 \mathrm{~km}$ ) resolution.

A daily meteorological data with a resolution of 10' (including precipitation, wet-day frequency, minimum and maximum temperature, relative humidity, solar radiation, and wind speed) was derived by combining two sources: the Princeton University Global Meteorological Forcing Dataset for Land Surface Modelling daily dataset with a resolution of $1^{\circ}$ (Sheffield et al., 2006) and the CRU monthly dataset for the period 1961-2006 with a 10' resolution (New et al., 2002).

Crop management is one of the most important inputs required for EPIC modelling. It consists of detailed schedules and characteristics of the most common crop operations (sowing, harvesting, tillage, fertilisation, irrigation, etc.) for each crop used in EPIC simulations. The management practices were derived at sub-national units using the administrative boundaries provided by FAO Sub-National Administrative boundaries Level 2 and 3 (FAO, 2009c). These administrative units of an average area of $7100 \mathrm{~km}^{2}$ were considered as the reference spatial scale for crop management.

Considering the available data resolution of soil, land use and crop management datasets, a reference spatial unit grid of $15 \mathrm{~km}$ x $15 \mathrm{~km}$ covering all the African territory was selected. The whole Africa was discretized into 135000 grid cells. Each grid cell, representing the unit for simulation, is characterized by an average topography, soil, and climate data. Maize, sorghum, wheat and barley are the most important cereals crop in Africa, with maize being the most important crop in Central and Southern Africa and wheat being the dominant crop in Northern Africa. So, for our study we applied the integrated tool (EPIC model-MOEA routine) for all these major crops in countries representative of different agricultural systems and environments of the African continent. The list of selected countries is given in Table 1 .

\subsection{Control Variables: Fertilization and Irrigation}

Fertilizer and irrigation strategies control crop yield production at local and global scale (Mueller et al., 2012) and they are directly managed by farmers. Consequently, variables related to fertilization and irrigation were used as model constraints to derive via the Multi-Objective Evolutionary Algorithm (MOEA) alternative management strategies from which the optimal solutions will be selected. Additional constraints (such as a minimum value for crop income or a maximum accepted value for nitrate leaching losses) were not considered not to limit the output information provided to final users. More specifically, for each crop, we considered the total amount of nitrogen fertilizer applied and also different strategies of application (number of applications by cropping season and minimum/maximum amount for each individual application). For irrigated crops, amount and scheduling of total water applied were also variables taken into account (Table 2).

The ranges of decision variables to be used via the MOEA to modify EPIC inputs and to perform random simulations are summarized in Table 2. The EPIC model was setup with the auto-fertilization and auto-irrigation options. With this configuration the model schedules automatically the management operations according to daily plant nitrogen and water stresses while respecting the values of variables described in Table 2. The plant stress threshold varies from 0 (no stress is considered) to 1 (no stress is allowed thus applications occur as soon as the stress is felt). The model was run for 20 years. For each year, the model calculates the amount of fertilizer and irrigation water to be applied for each crop according to the decision variables (decision triggers), the climatic conditions, and the soil characteristics.

Ranges were set up to the maximum extent allowed by the model for water and fertilizer stress ( 0 to 1$)$ while maximum constraint values for other parameters were set choosing a reasonable agronomic value. For instance according to statistical data reference average fertilization in Africa is about 20 $\mathrm{kg} / \mathrm{ha}$, so we considered a maximum ranging between $200 \mathrm{~kg}$ /ha and $700 \mathrm{~kg} / \mathrm{ha}$ as sufficient to describe a potential increase for all major crops.

\subsection{The Optimization Method}

It is important to note that, for a given crop, the yield could increase by a factor 2 to 3 with the appropriate application of water and fertilizers. However, this increase is not linear and depends on the interactions between the amounts and timing of application of both fertilizers and irrigation, and on other factors including climate and soil characteristics. Objective functions arising from real world problems do not ensure nice mathematical properties as required by many optimization methodologies (Sarker and Ray, 2009). Thus, we apply a Multi-Objective Evolutionary Algorithm (MOEA) that is capable of dealing efficiently with most of this mathematical function complexities. We have adapted the C-sharp implementation of the MOEA by Udías et al. (2011). This algorithm applies binary gray encoding (Goldberg, 1989) for each "chromosome" (optimization string) to represent agronomic strategies (variables of Table 2). Each "gene" uses 7 bits to encode the value of each variable, so the total length of the chromosome is 42 bits ( 6 var $\times 7$ bit/var). The MOEA algorithm evaluates the objective functions fitness based on the outputs of EPIC and the economic model described in the next section.

The initial population is generated randomly if no previous management information is available. The implementation of the algorithm uses the usual procedures of selection (tournament), crossover (single point), and mutation (bit inversion) to generate the new population. It also introduces elitism by maintaining an external population. In each generation, the new solutions that belong to the internal population 
Table 1. Crop Values, Water and Fertilizer Costs for the Countries Considered in the Analysis

\begin{tabular}{llllll}
\hline \multicolumn{7}{l}{ Crop value [US \$ tons $\left.{ }^{-1}\right]$} & & & Water irrigation cost [US \$ $\left.100 \mathrm{~mm}^{-1}\right]$ \\
\hline Country & Maize & Wheat & Barley & Sorghum & \\
\hline Algeria & 270 & 340 & 210 & 160 & 7 \\
Congo DEM & 370 & n.a. & n.a. & n.a. & 9 \\
Ethiopia & 180 & 280 & 250 & 230 & 12 \\
Kenya & 310 & 300 & 260 & 270 & 9 \\
Libya & n.a. & 280 & 250 & n.a. & 5 \\
Morocco & 250 & 280 & 220 & 300 & 7 \\
Mozambique & 150 & n.a. & n.a. & 140 & 9 \\
Nigeria & 375 & n.a. & 230 & 330 & 8 \\
South Africa & 140 & 210 & 200 & 150 & 7 \\
Tunisia & n.a. & 250 & 160 & n.a. & 29 \\
\hline
\end{tabular}

Table 2. Range of the Decision Variables Considered in All the Analyses

\begin{tabular}{llll}
\hline Parameter & Description & Minimum & Maximum \\
\hline BIR & Water stress & 0 & 1 \\
VIMX & Maximum annual irrigation $(\mathrm{mm})$ & 20 & 900 \\
ARMX & Maximum irrigation in single application $(\mathrm{mm})$ & 50 & 80 \\
ARMN & Minimum irrigation in single application $(\mathrm{mm})$ & 10 & 60 \\
BFT0 & Fertilizer stress & 0 & 1 \\
FMX & Maximum annual fertilization $(\mathrm{kg} / \mathrm{ha})$ & 200 & 700 \\
\hline
\end{tabular}

and are not Pareto dominated by any solution of the external population, are moved to the external population. If the solutions of the external population are dominated by some of the new solutions, these solutions are deleted from the external population. The external elitist population is simultaneously maintained in order to preserve the best solutions found during the iterative process and to incorporate part of the information in the main population by means of the crossover. Elitism is also included in the recombination process, selecting each of the parents through a fight (tournament), between two randomly-selected chromosomes from the external Pareto set (according to a density criterion) or from the population set (according to a ranking determined through a dominance criterion). Three recombination possibilities are also implemented in the algorithm: crossover of two chromosomes from the external Pareto set, crossover of two chromosomes from the previous population, and crossover of one chromosome from the previous internal population with another from the external elitist population.

After a parameter tuning phase, the algorithm gets a set of near-optimal trade-off solutions with less than 2,000 evaluation of the model (with a population size of 10 and a mutation rate of $3 \%$ ). Using a higher number of evaluations (tested for a sub sample of the data) proved to introduce a very limited increase in the process performance as indicated by the limited difference (less than 5\%) between the two $(2,000$ vs 20,000 evaluations) resulting hypervolumes. The hypervolume is used as a valid index of convergence of multi-objective problem (Deb, 2001). Since the execution of the EPIC model at continental scale has high computational require- ments and the results are an approximation of the real value (both monetary and nitrate leaching), we have considered this level of convergence as an adequate compromise solution.

\subsection{Objective Function}

Our analysis considered only two objectives since multiplying the number of objectives increases the computational effort and enhances the complexity of interpreting the tradeoff solutions curves. The objectives used during the optimization process are defined as follows:

(a) Minimization of the environmental impact of the agricultural strategy. Average nitrate leaching below the root zone is selected as a proxy for the environmental impact, since nitrogen loss from agricultural sources is a major contributor to water quality degradation (Sutton et al., 2011):

$N l_{a v}=\frac{1}{A(c)} \sum_{i=1}^{N_{\text {cells }}} N l_{i} * A_{i}(c)$

where:

$N l_{a v}:$ nitrate leaching average $(\mathrm{kg} \mathrm{N} / \mathrm{ha})$;

$c$ : specific crop;

$i$ : index of the cells in the country;

$N_{\text {cells }}$ : total number of cells in the country;

$A(c)$ : total crop area (ha) in the country;

$A_{i}(c)$ : area (ha) of crop $c$ in cell $i$; 

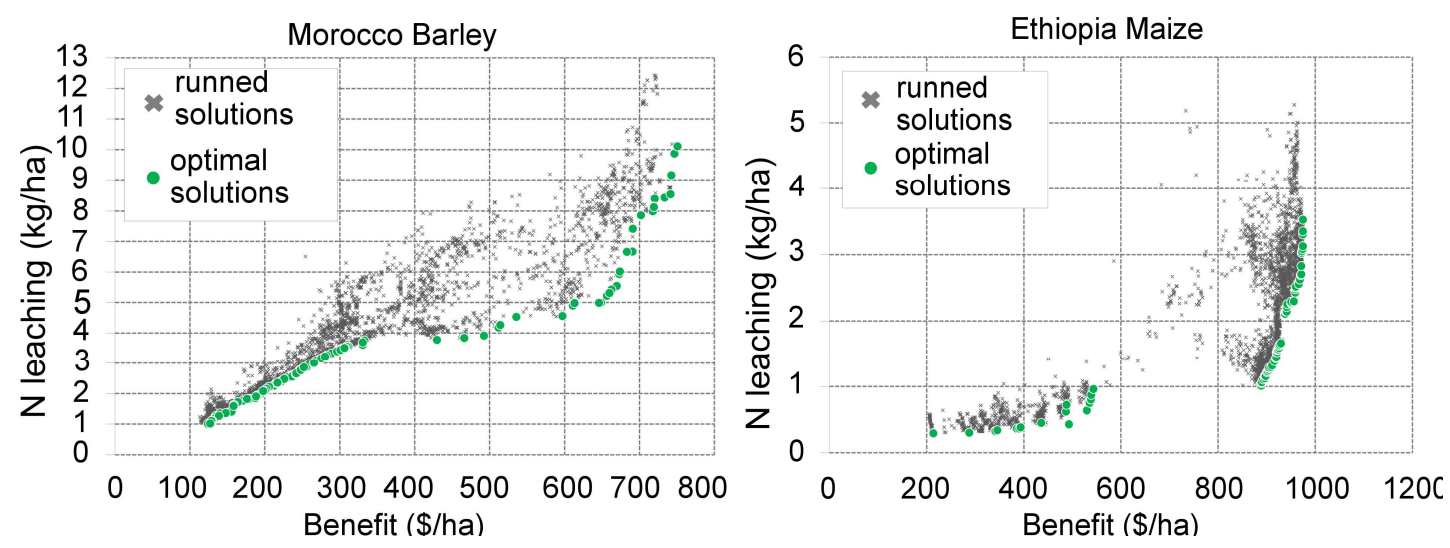

Figure 2. Simulated (grey cross) and Pareto solutions (green dots) obtained when maximizing the economic benefit and minimizing $\mathrm{N}$ leaching for barley for one region in Morocco (left) and for maize in one region in Ethiopia (right).

$\mathrm{Nl}_{i}$ : nitrate leaching in the cell $i(\mathrm{~kg} \mathrm{~N} / \mathrm{ha})$.

(b) Maximization of the net income based on crop yield and water and fertilizer costs computed according to the following equation:

$$
\begin{aligned}
& N I(c)=\sum_{i=1}^{N_{\text {cells }}} A_{i}(c)\left[Y_{i}(c) * S P(c)\right. \\
& \left.-W C_{i}(c) * W P-F C_{i}(c) * F P\right]
\end{aligned}
$$

where:

$N I(c)$ : net income (US $\$ /$ ha) for the crop $c$;

$Y_{i}(c)$ : yield average (tons/ha) of crop $c$ in cell $i$;

$S P(c)$ : selling price (US $\$ /$ tons) for the crop $c$ in the country (Table 2);

$W C_{i}(c)$ : irrigation water use $\left(\mathrm{m}^{3} / \mathrm{ha}\right)$ for the crop $c$ in cell $i$; $W P$ : irrigation water cost (US $\$ / \mathrm{m}^{3}$ ) in the country (Table 2);

$F C_{i}(c)$ : fertilizer use $(\mathrm{kg} / \mathrm{ha})$ for the crop $c$ in cell $i$;

$F P$ : fertilizer cost (US $\$ / \mathrm{kg}$ ) in the country (Table 2 ).

\subsection{Economic Information}

The economic analysis was performed considering the potential income deriving from the selling of the crop on the local market and the management costs linked to the different management practices adopted (fertilization and irrigation costs). More specifically, for each crop the selling price was considered homogenous at country level and the average value was calculated from FAO statistical data (FAOSTAT, 2014) using the last 10 years of the simulation period (Table 1). We used a 10 year average because the focus of this study was to identify management practices that can be adopted on the long-term. We considered the average price of two important fertilizers commonly used and available on the African market: di-ammonium phosphate (DAP) and urea with an average cost of 1.7 and 0.5 US $\$$ per $\mathrm{kg} \mathrm{N} \mathrm{ha}^{-1}$, respectively. A generic cost of 1.1 US \$ per $\mathrm{kg} \mathrm{N} \mathrm{ha}^{-1}$ was used for all countries. The impact of the fertilizer price will be assessed in a section dedicated to sensitivity analysis.

Having an accurate estimate of the water cost is an important issue when performing a trade-off assessment of cost benefit of alternative management practices. Water cost is variable year by year and depends on many variables such as the availability of water, the type of irrigation applied and the investments cost required to set up the irrigation plant. In our analysis we considered only the operating costs since the focus of the research is on the assessment of different management practices rather than on evaluating the pertinence of developing new irrigation projects.

The long term average operating water cost for each country (10 year average) was approximated by considering the use of a pump to extract water from the aquifer and/or distribute water in the field. The water cost depends on the diesel cost and the well depth. The method and the equation used for the calculation are described in detail in Hogan et al. (2007), and the calculated prices are given in Table 1. The estimated costs are within the range of reported national values (Chohin-Kuper and Strosser, 2008).

\section{Results}

Trade-offs between different objectives are presented as Pareto front solutions that are the final output that end users can use to drive their decision. The Pareto trade-off strategies are calculated for each crop and each country (Figures 2-6). All the selected control variables (Table 2) are related to the fertilization and irrigation operations, so the resulting best management practices will be linked to these two agricultural management aspects.

As illustrated in Figure 2 the tool runs a large number of management combinations (small grey dots) trying to find the optimal solutions. The cloud of points (solutions) presented in the graph is denser close to the Pareto front because the MOEA iteratively redefines improved sets of management variables to be tested, and determines approximate near-optimum solutions (taking into account the uncertainty of the con- 


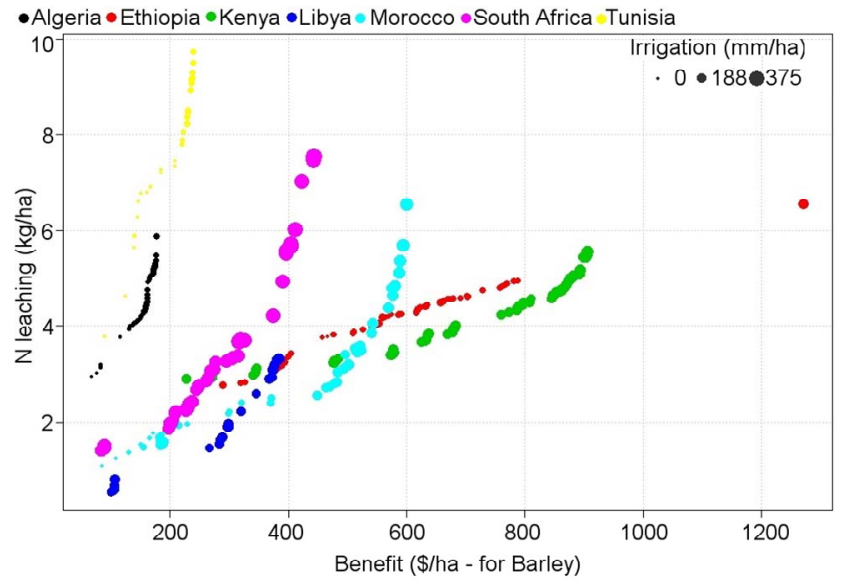

Figure 3. Pareto solutions by country obtained when maximizing the economic benefit and minimizing $\mathrm{N}$ leaching for barley. The pixel size represents the magnitude of applied irrigation water.

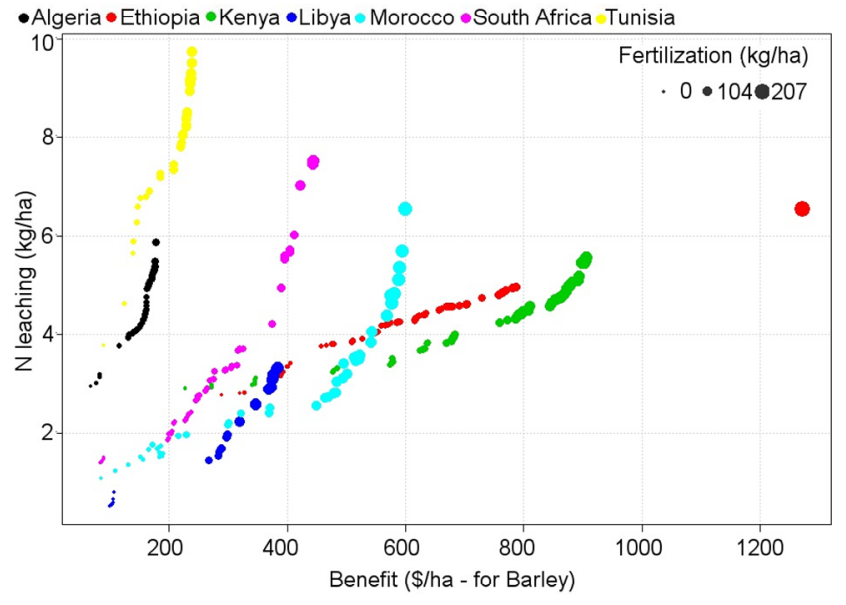

Figure 4. Pareto solutions by country obtained when maximizing the economic benefit and minimizing $\mathrm{N}$ leaching for barley. The pixel size represents the magnitude of fertilization input.

sidered problem) in less than 200 iterations. It can be seen in Figure 2 that for barley in Morocco and maize in Ethiopia, the Pareto curves show similar trends with the benefits initially increasing significantly while nitrogen leaching is increasing moderately. After a cut-off point, the Pareto curves show that the production can no longer be increased significantly while nitrogen leaching increases exponentially. This indicates that even with additional fertilizer or irrigation water (in irrigated areas) the yield will not increase significantly (maximum yield reached with the proposed management strategy). In this part of the Pareto curve, the proposed management strategies will lead to a significant increase of nitrogen leaching since the excess fertilizer applied can no longer be taken up by crops.

The generated Pareto curves for single crops indicate best management practices specific to the studied area (Figures 3-8). In all African countries the increase of benefit is always related to a higher amount of nitrate losses to the environment. However, substantial variations and different patterns can be observed among the countries. The increase of $\mathrm{N}$ leaching per unit income increase varies significantly among countries depending on local climatic and soil conditions (factors that can facilitate or limit nitrogen losses), especially in the case of high productive management practices. For example, the shape of the barley Pareto front for Algeria and Tunisia (very steep) is very different from that for Kenya and Ethiopia. In Algeria, crop production is nearly optimal under the current management strategies (Table 3). Barley is irrigated in very limited areas, and crop production is water limited in Tunisia and Algeria (Pastori et al., 2011). Hence, increasing the amount of applied water in irrigated areas will not result in any significant increased income (Figure 3). On the other hand, in Tunisia, where the yield of barley could potentiality double, the increase of fertilization and irrigation inputs can lead to an additional production, but with limited benefit because of the high water cost and especially high nitrogen losses (Figures 3 and 4). In South Africa, crop production is strongly dependent on water availability with large areas being irrigated but with low amounts of fertilizers applied. Thus, increasing nitrogen application will result in higher benefits however with increased nitrogen losses. In South Africa, the increase of benefit is independent from the irrigation amount (amount of water applied is optimal under current management practices for barley). For all countries after a specific tipping point the relation $\mathrm{N}$ leaching vs benefit starts to increase much more rapidly. This steeper slope of the curves indicates that the farmer can gain less net benefit for the same additional net environmental impact or, in other words, that it is necessary to accept a higher pollution to achieve the same amount of economic benefit.

All previous conclusions can be also extended to other crops. For example in the case of maize (Figures 5 and 6) we focused the analysis in central and southern countries, where the crop is dominant. Nigeria shows important potential for benefit increase: this partially depends on the crop price that is quite high on the local market (380 US \$ tons in the period 2000 2009), and also on the high water availability (no or very limited irrigation is required) that reduces the management costs required to increase the yield. For all the countries it is possible to identify the value of threshold benefit beyond which the environmental impact starts to increase disproportionally: in the case of South Africa after a benefit of 1300 \$/ha the Pareto curve tends almost to be vertical. In the case of Mozambique the resulting Pareto front is especially steep indicating that any small increase in crop production and so in farmers' benefit is coupled to high nitrogen losses. This specific behaviour is linked to the presence of highly draining soils (arenosols) in this country where the cultivation of maize is both water and nitrogen limited. The dependence of the yield on the fertilization strategy is shown in Figure 5 for barley and maize. Yields are higher where water is less limited and, conversely, lower where water availability is limiting crop 


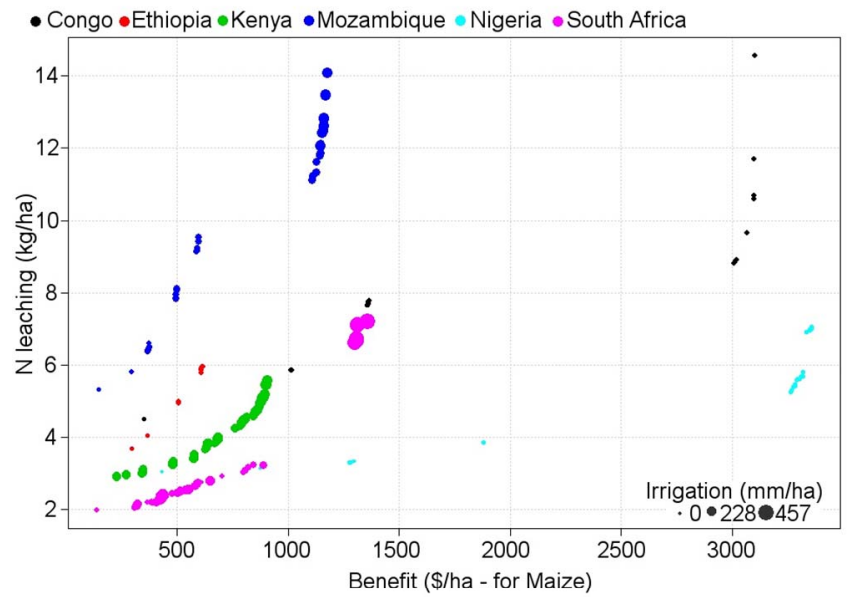

Figure 5. Pareto solutions by country obtained when maximizing the economic benefit and minimizing $\mathrm{N}$ leaching for maize. The pixel size represents the magnitude of applied irrigation water.

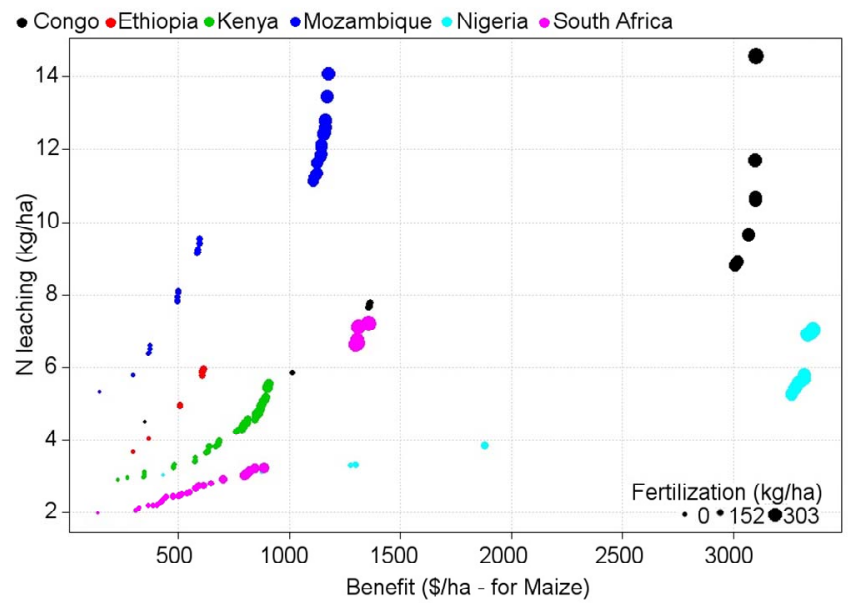

Figure 6. Pareto solutions by country obtained when maximizing the economic benefit and minimizing $\mathrm{N}$ leaching for maize. The pixel size represents the magnitude of fertilization input.

growth (Tunisia and Algeria). The optimal solutions show a clear linear relationship between yield increase and fertilizer application; for some countries it is also possible to identify the tipping point at which the yield increase becomes more limited (in South Africa, Tunisia and Kenya for barley and Kenya, Congo and Nigeria for maize). The actual yield for barley and maize for the selected countries is given in Table 3. Most of the countries are still in a low input production system, and the optimization tool indicates large potential increase of yield while preserving natural resources. It can be seen that based on the yields reported in Table 3, Figures 7 and 8 that for barley, Libya, Tunisia are in the lower part of the Pareto curve, while South Africa, and Kenya in particular are in the higher part of the Pareto curve. The actual yield in Kenya is around 3 tons/ha with an estimated maximum opti- mal yield around 4 tons/ha, while for Morocco the actual yield is less than 1 ton/ha and the estimated optimum yield around 3.5 tons/ha.

One of the main outcomes of these analyses is that it is possible for each country to identify a specific Pareto front that is closely related to the specific local characteristics of the country, such as climate and soils. In our study we considered generalized average costs that can potentially vary and fluctuate year by year. This variability was not taken into account in this analysis. We tested the impact of varying the input costs in a range of $50 \%$ for selected crops and countries. In general no drastic change was observed as illustrated for barley in Morocco (Figure 9). The shape of the Pareto front did not change significantly, in particular in the initial linear part of the curve. The most significant difference occurs in the tipping point, which moves to the right at lower costs. In particular, the price of fertilizer shows the largest impact. At the current cost, the tipping point is at around $490 \$ / \mathrm{ha}$. When the price of fertilizer is reduced, the tipping point occurs at a benefit of $550 \$ /$ ha, while when fertilizers become more expensive, the tipping points corresponds to a benefit of 410 \$ha.

Because the optimization process has a significant stochastic component, each Pareto set comprises a different number of solutions that are distributed not uniformly along the Pareto front. In order to limit this effect in our comparative analysis, we sub-sampled the original Pareto set distribution to se lect the same number of points distributed as uniformly as possibly. The analysis was performed several times repeating the sub-sampling process.

Table 3. Reported Barley and Maize Yield (FAOSTAT, 2014) for the Countries Considered in the Analysis

\begin{tabular}{lll}
\hline & Barley yield (ton/ha) & Maize yield (ton/ha) \\
\hline Algeria & 1.27 & 4.07 \\
Congo & N/A & 0.81 \\
Ethiopia & 1.26 & 1.99 \\
Kenya & 3.02 & 1.62 \\
Libya & 0.49 & 2.15 \\
Morocco & 0.88 & 0.67 \\
Mozambique & N/A & 0.88 \\
Nigeria & N/A & 1.68 \\
South Africa & 2.46 & 3.44 \\
Tunisia & 1.02 & N/A \\
\hline
\end{tabular}

\section{Discussion}

The multi-objective optimization approach applied provides Pareto curves according with one economic (global farmers Income) and one environmental objective (nitrogen leaching below the root zone). For some of the trade-off resulting curves, the solutions are not perfectly distributed along the 
efficient frontier for some of the executions (even with the best set of the MOEA parameter configuration). This is because the optimization process is stopped after 2000 evaluations (with 10 chromosomes/generation) in order to reduce computation times. However the final trade-off curves are close enough to the Pareto frontier, and they provides accurate optimized solutions.

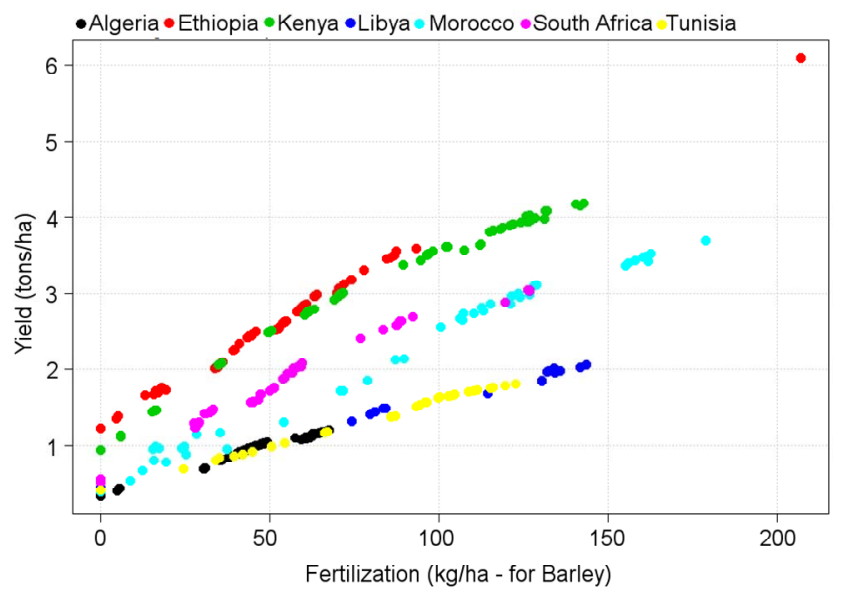

Figure 7. Relation between the quantity of fertilizer applied (FTN) and the yield obtained for barley in selected African countries. All the solutions are Pareto optimal considering the maximization of economic benefit and minimization of nitrate percolation.

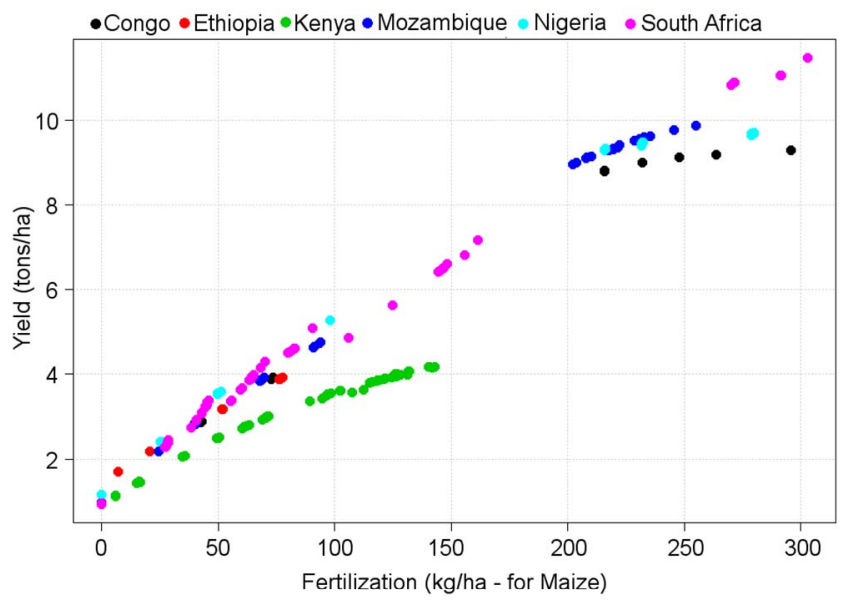

Figure 8. Relation between the quantity of fertilizer applied (FTN) and the yield obtained for maize in selected African countries. All the solutions are Pareto optimal considering the maximization of economic benefit and minimization of nitrate percolation.

The tool can be used by managers to choose optimized solutions for increasing crop production to limit the dependency on crop import. For instance, wheat is one of the major crops in Morocco and accounts for $42 \%$ of the total agricultural harvested area according to FAO statistics (FAOSTAT,
2014). Although the production of wheat in Morocco is one of the highest in Africa and the average yield per ha has increasing in the last years, the production is not yet sufficient to satisfy entirely the local demand, in particular during the periods of lower production (for example, during 2009-2012 period the yield decreased from 2.1 to 1.2 tons/ha). We can observe (Figure 10) that the optimal management solutions identified in the Pareto front result in a wide range of economic and environmental outcomes. All the selected solutions are optimal but they have different impact on farmers' income, stakeholders' interests, and environmental impact. For example, the optimal solution identified in the Figure 10 (top-left) as optimal-1, is characterized by very low fertilizer input $(\mathrm{N}$ input less than $20 \mathrm{~kg} / \mathrm{ha}$ ); while it is very protective for the environment (resulting in a very limited $\mathrm{N}$ leaching), it may be not acceptable from a farmer's perspective. The optimal-2 and optimal-3 solutions are characterized by a medium input management, with an average fertilization of $50-70 \mathrm{~kg} / \mathrm{ha}$ and an irrigation water use of $180 \mathrm{~mm}$ and $210 \mathrm{~mm}$, respectively. The high input solution (optimal-4) is characterized by a very high use of fertilizer and water resources $(\mathrm{N}$ input $180 \mathrm{~kg} / \mathrm{ha}$, irrigation $300 \mathrm{~mm} / \mathrm{ha} / \mathrm{y}$ ) that could potentially harm the environment and lead to an overuse of water resources.

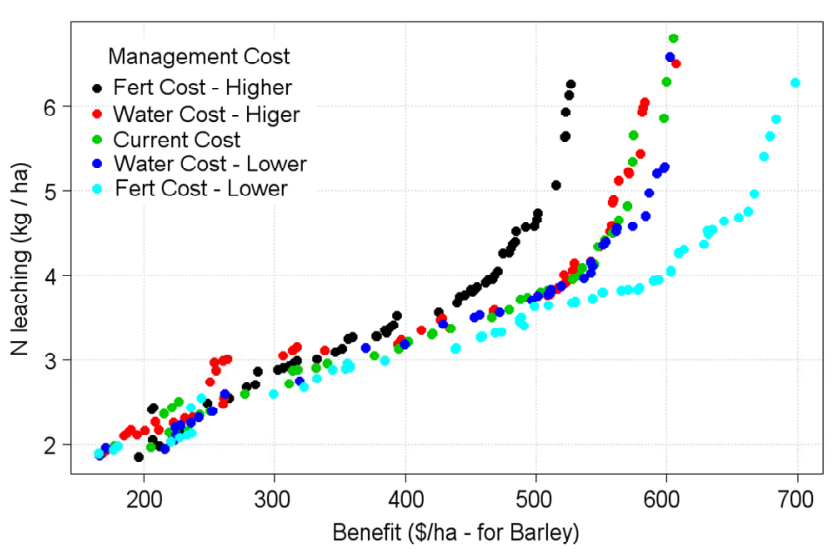

Figure 9. Pareto solutions obtained in Morocco considering the maximization of the benefit and the minimization of the $\mathrm{N}$ leaching for barley for various fertilizers and irrigation costs.

Actual management practices are non-optimal (see dark point in Figure 10) with production levels comparable to optimal-1 scenario (corresponding to the lowest benefit for farmers) and moderate nitrogen leaching. As a result, the country has to import high quantities of wheat and other cereals: for example the value of the imported wheat in 2011 was of about $1300 \mathrm{M} \$, 70 \%$ of Morocco total import value for cereals (FAOSTAT, 2014). The optimization tool indicates the possibility to move towards more profitable yield production while preserving at the same time the environment (limiting nitrate leaching). The "medium input" scenarios (Figure 10) show a set of optimal solutions that correspond to a very significant increase of the yield, reaching a potential average production ranging between 2.2 and 3.3 tons/ha/y. Current need 

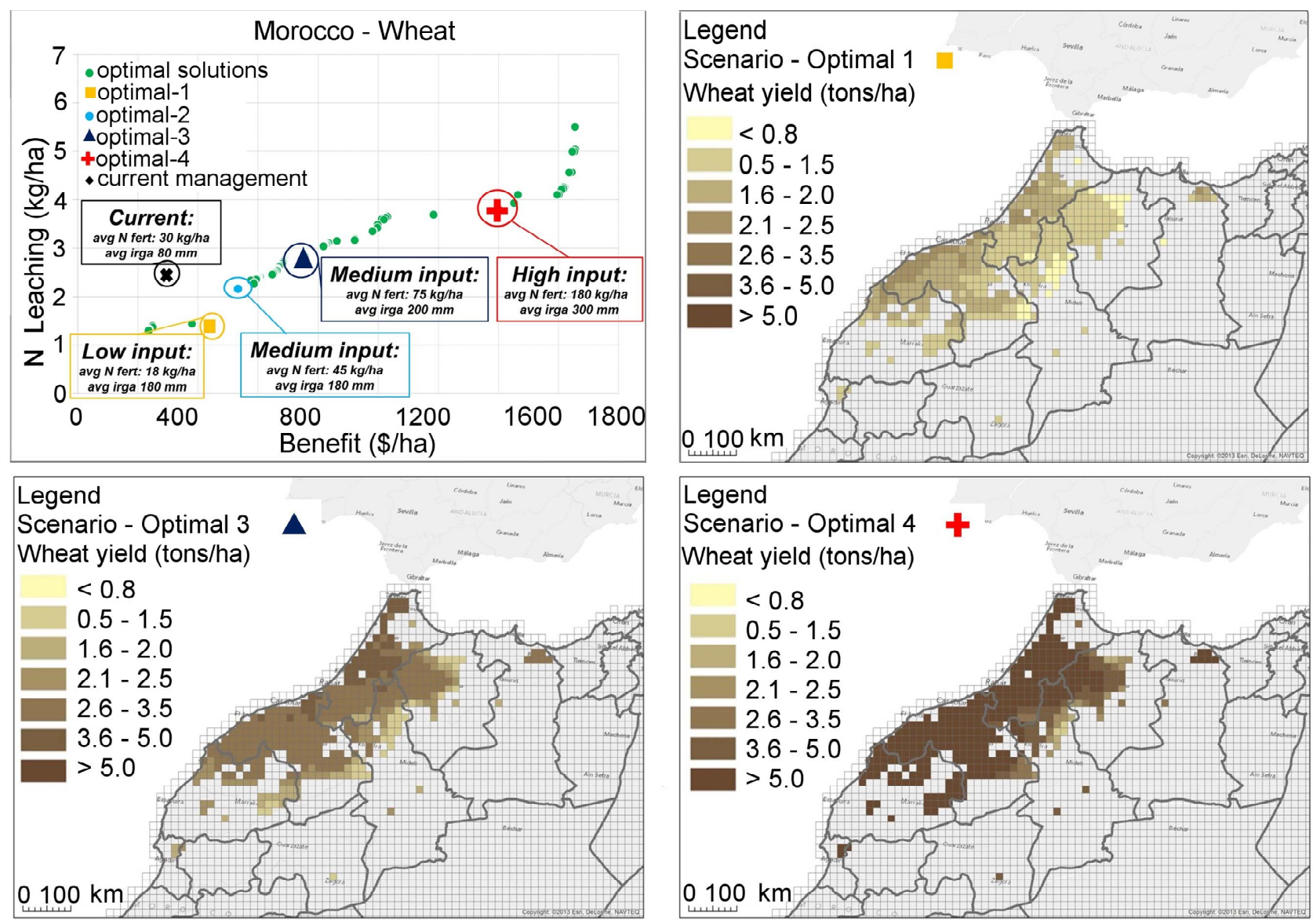

Figure 10. Predicted wheat yields maps for 3 optimal management solutions obtained with the application of the optimization algorithm. The 3 maps correspond to the yellow, blue and red circled symbols in the top-left figure (Pareto solutions for wheat).

for wheat in Morocco is around 9.5 Mtons (year 2011 production plus import, FAOSTAT, 2014). To be self-sufficient for wheat, an average yield of 3.1 tons/ha would be required considering the total harvest area of 3 Mha. This yield level corresponds to the optimal-3 solution that, notwithstanding a medium/high use of fertilizer and irrigation, is environmentally sustainable and results in higher farmer income.

According to our analysis the increase of nitrogen input is the most adequate solution to increase crop yields in Morocco. Conversely, irrigation does not appear to have a significant potential impact. This is because the area of barley cultivation being actually irrigated is limited (around 4\% according to FAOSTAT). Indeed we tested only changing the application rates, not extending the irrigated areas. Nonetheless, increasing irrigation in Morocco is feasible. According to Aquastat (FAO, 2010), an important part of the total Moroccan available water resources $\left(154.5 \mathrm{~km}^{3} / \mathrm{y}\right)$ are not yet exploited (the current total water withdrawal is $12.6 \mathrm{~km}^{3} / \mathrm{y}$ ).

\section{Conclusions}

African agriculture is one of the less productive because of low use of available water resources and of limited ferti- lizer inputs that is one-tenth of the world average. It is expected that African agriculture will shift to more productive farming systems to face growing food and products demand of the local market. In this context, the application of supporting tools for the identification of best management practices that can minimize the impact on the environment, including water quality degradation and sustainable use of water resources, while preserving at the same time the benefit for farmers is important. Literature so far has focused solely on gap analysis, without considering water requirement or the environmental impact of the proposed management practices. In our study a multi-objective optimization tool has been linked to a crop management simulation model (EPIC) in order to identify optimal best management practices for different crops and countries in Africa while considering the sustainability of the natural resources.

Even though we focused our analysis at the country scale, the tool also provides information at higher resolution that can be used by decision makers for local and regional management. In addition, if required the tool can be downscaled in order to accommodate regional specificities (costs, projected increased irrigated areas, etc.). We show that current management practices are, in general, inefficient solutions or corre- 
spond to the lowest values of potential production and benefits that farmers can realize. This implies that African farmers can improve their gross margin while preserving at the same time the environment. However, it has been shown that moving towards higher input management options (even if optimal) can lead to significant impact on water quality.

The proposed solutions provide a wide range of local management strategies for optimizing farmers' benefit while considering the environmental impacts, but the final choice of decision-makers may also consider additional factors, such as the socio-economic aspects. The methodology is based on objective quantitative data and gives valuable information to decision-makers. It can be easily modified to incorporate additional criteria for inclusion in the optimization process. This type of approach also offers the possibility of integrating in the decision criteria all major concerns of all stake-holder.

However, is important to quantify the impact of the various inputs on the results of the optimization. In particular, future research should evaluate how representative of current conditions the soil characteristics are (e.g. organic carbon content). Indeed, organic content values reported by the FAO et al. (2012) may no longer be up to date since it has been reported widely that nutrient mining is taking place in Africa, affecting the prediction of crop yield. Similarly, it will be necessary to evaluate the impact of climate variability and potential climate change on the optimization results. At the scale of the study, it might not be necessary to look for more detailed input data as they might not improve the yield prediction (Waha et al., 2015). Instead, it will be more critical to evaluate how the model responds to critical shocks (climate change, droughts) both in time and space. In addition, comparable studies based on other crop growth models will be necessary as several authors have reported that the selection of the crop growth model introduces more uncertainties in the predictions than that linked to the spatial and temporal resolution of the input data (Angulo et al., 2013).

\section{References}

Angulo, C., Rötter, R., Trnka, M., Pirttioja, N., Gaiser, T., Hlavinka, P., and Ewert, F. (2013). Characteristic 'fingerprints' of crop model responses to weather input data at different spatial resolutions. Eur. J. Agron., 49, 104-114. http://dx.doi.org/10.1016/j.eja.2013.04.003

Arabatzis, S., and Manos, B. (2005). An integrated system for water resources monitoring, economic evaluation and management. Oper. Res., 5(1), 193-208. http://dx.doi.org/10.1007/BF02944171

Bates, B.C., Kundzewicz, Z.W., Wu, S., and Palutikof, J.P. (2008). Climate Change and Water: Technical Paper of the Intergovernmental Panel on Climate Change, IPCC Secretariat, Geneva.

Bouraoui, F., and Grizzetti, B. (2014). Modelling mitigation options to reduce diffuse nitrogen water pollution from agriculture. Sci. Total Environ., 468-469, 1267-1277. http://dx.doi.org/10.1016/j.sci totenv.2013.07.066

Bryan, B.A., and Crossman, N.D., (2008). Systematic regional planning for multiple objective natural resource management. $J$. Environ. Manage., 88(4), 1175-1189. http://dx.doi.org/10.1016/j.j envman.2007.06.003

Chohin-Kuper, A., and Strosser, P. (2008). Water pricing in Europe and around the Mediterranean Sea: Issues and options. Proc. of the Fourth European Water Association Conference, Brussels. http:// www.dwa.de/portale/ewa/ewa.nsf/C125723B0047EC38/90E45AE C74290744C1257563003484E7/\$FILE/EWA2008_Chohin_Stross er_conf.pdf (accessed Dec 1, 2014).

Deb, K. (2001). Multi-Objective Optimization Using Evolutionary Algorithms, John Wiley \& Sons. ISBN: 978-0-471-87339-6.

Easterling, W., and Apps, M. (2005). Assessing the consequences of climate change for food and forest resources: A view from the IPCC. Clim. Change, 70(1-2), 165-189. http://dx.doi.org/10.1007/s 10584- 005-5941-0

FAO (2009a). The special challenge for Sub-Saharan Africa "How to Feed the World 2050", Proc. of the How to Feed the World in 2050 High-level experts Forum, Rome.

FAO (2009b). SRTM 30 arc second DEM, FAO Geonetwork. http:// www.fao.org/geonetwork/ (accessed Jan 1, 2011).

FAO (2009c). Subnational-Ad3/Ad2 Boundaries, FAO Geonetwork. http://www.fao.org/geonetwork/ (accessed Jan 1, 2011).

FAO (2010). AQUASTAT global water information system. http:// www.fao.org/nr/water/aquastat (accessed Jan 1, 2011).

FAO, IIASA, ISRIC, ISSCAS, and JRC (2012). Harmonized World Soil Database (version 1.2), FAO, Rome, Italy and IIASA, Laxenburg, Austria.

FAOSTAT (2014). Faostatistics Database. http://faostat3.fao.org/ (accessed Sep 1, 2014).

Fernandez-Santos, J., Zekri, S., and Casimiro Herruzo, A. (1993). On-farm costs of reducing nitrogen pollution through BMP. Agric., Ecosyst. Environ., 45(1-2), 1-11. http://dx.doi.org/10.1016/01678809(93)90055-T

Fetouani, S., Sbaa, M., Vanclooster, M., and Bendra, B. (2008). Assessing ground water quality in the irrigated plain of Triffa (north-east Morocco). Agric. Water Manage., 95(2), 133-142. http: //dx.doi.org/10.1016/j.agwat.2007.09.009

Fianko, J.R., Osae, S., and Achel, D. (2009). Impact of anthropogenic activities on the Densu River in Ghana. Water Environ. J., 23(3), 229-234. http://dx.doi.org/10.1111/j.1747-6593.2008.00 137. $\mathrm{x}$

Fleshman, M. (2006). Boosting African farm yields, in Africa Renewal, United Nations Department of public Information, vol. 20, 2, pp. 10-12. http://www.un.org/ecosocdev/geninfo/afrec/maga zine.html (accessed Feb 1, 2012).

Folberth, C., Gaiser, T., Abbaspour, K.C., Schulin, R., and Yang, H. (2012). Regionalization of a large-scale crop growth model for sub-Saharan Africa: Model setup, evaluation, and estimation of maize yields. Agric., Ecosyst. Environ., 151, 21-33. http://dx.doi. org/10.1016/j.agee.2012.01.026

Galloway, J.N., Townsend, A.R., Erisman, J.W., Bekunda, M., Cai, Z., Freney, J.R., Martinelli, L.A., Seitzinger, S.P., and Sutton, M.A. (2008). Transformation of the nitrogen cycle: Recent trends, questions, and potential solutions. Science, 320(5878), 889-892. http:// dx.doi.org/10.1126/science.1136674

Gassman, P.W., Williams, J.R., Benson, V.W., Izaurralde, R.C. Hauck, L., Jones, C.A., Atwood, J.D., Kiniry, J., and Flowers, J.D. (2005). Historical Development and Applications of the EPIC and APEX Models, Working Paper 05-WP 397, Center for Agricultural and Rural Development, Iowa State University. http://www.card. iastate.edu/publications/DBS/PDFFiles/07wp443pdf.

Gómez-Limón, J.A., and Riesgo, L. (2004). Irrigation water pricing: Differential impacts on irrigated farms. Agric. Econ., 31(1), 47-66. http://dx.doi.org/10.1016/j.agecon.2003.02.001

Goldberg, D.E. (1989). Genetic Algorithms in Search, Optimization and Machine Learning, Addison-Wesley Longman Publishing Co., Inc. Boston, MA, USA.

Hans, A.E. (1988). Multicriteria optimization for highly accurate 
systems, in W. Stadler (Ed.), Multicriteria Optimization in Engineering and Sciences, Mathematical Concepts and Methods in Science and Engineering, Plenum Press, vol. 19, pp. 309-352.

Higgins, A.J., Hajkowicz, S., and Bui, E. (2008). A multi-objective model for environmental investment decision making. Comput. Oper. Res., 35(1), 253-266. http://dx.doi.org/10.1016/j.cor.2006.02. 027

Hogan, R., Stiles S., Tacker, P., Vories, E., and Bryant, K.J. (2007). Estimating Irrigation Costs - FSA28, University of Arkansas, Division of Agriculture. http://www.uaex.edu/Other_Areas/publications /PDF/FSA-28.pdf (accessed Sep 1, 2012).

Ines, A.V.M., Honda, K., Das Gupta, A., Droogers, P., and Clemente, R.S. (2006). Combining remote sensing-simulation modeling and genetic algorithm optimization to explore water management options in irrigated agriculture. Agric. Water Manage., 83(3), 221232. http://dx.doi.org/10.1016/j.agwat.2005.12.006

IPCC (2007). Climate Change 2007: Mitigation. Contribution of Working Group III to the Fourth Assessment Report of the Intergovernmental Panel on Climate Change, Cambridge, United Kingdom and New York, NY, USA.

Latinopoulos, D. (2009). Multicriteria decision-making for efficient water and land resources allocation in irrigated agriculture Environ. Dev. Sustainability, 11(2), 329-343. http://dx.doi.org/10. 1007/s10668-007-9115-2

Jegannathan, C., Roy, P.S., and Jha, M.N. (2011). Multi-objective spatial decision model for land use planning in a Tourism District of India. J. Environ. Inf., 17(1), 1-14. http://dx.doi.org/10.3808/jei. 201100182

Liu, J., Fritz, S., van Wesenbeeck, C.F.A., Fuchs, M., You, L., Obersteiner, M., and Yang, H. (2008). A spatially explicit assessment of current and future hotspots of hunger in Sub-Saharan Africa in the context of global change. Global Planet. Change, 64 (3-4), 222-235. http://dx.doi.org/10.1016/j.gloplacha.2008.09.007

Liu, J., Zehnder, A.J.B., and Yang, H. (2009). Global consumptive water use for crop production: The importance of green water and virtual water. Water Resour. Res., 45(5), W05428. http://dx.doi.org/ 10.1029/2007WR006051

Maherry, A., Tredoux, G., Clarke, S., and Engelbrecht, P. (2008). State of nitrate pollution in groundwater in South Africa. CSIR Pub. http://researchspace.csir.co.za/dspace/bitstream/10204/4288/1/Mah erry_2010_P.pdf (accessed Dec 1, 2014).

Manos, B., Begum, M.A.A., Kamruzzaman, M., Nakou, I., and Papathanasiou, J. (2007). Fertilizer price policy, the environment and farms behavior. J. Policy Model., 29(1), 87-97. http://dx.doi. org/10.1016/j.jpolmod.2006.05.002

Manos, B., Papathanasiou, J., Bournaris, T., and Voudouris, K. (2010). A multicriteria model for planning agricultural regions within a context of groundwater rational management. J. Environ. Manage., 91(7), 1593-1600. http://dx.doi.org/10.1016/j.jenvman.2010.03.002

Manos, B., Chatzinikolaou P., and Kiomourtzi, F. (2013). Sustainable optimization of agricultural production. APCBEE Procedia, 5, 410415. http://dx.doi.org/10.1016/j.apcbee.2013.05.071

Meyer, B.C., Lescot, J.M., and Laplana, R. (2009). Comparison of two spatial optimization techniques: A framework to solve multiobjective land use distribution problems. Environ. Manage., 43(2), 264-281. http://dx.doi.org/10.1007/s00267-008-9225-0

Monfreda, C., Ramankutty, N., and Foley, J.A. (2008). Farming the planet: 2. Geographic distribution of crop areas, yields, physiological types, and net primary production in the year 2000. Global Biogeochem. Cycles, 22(1), GB1022. http://dx.doi.org/10.1029/20 07GB002947

Morris, M., Binswanger-Mkhize H.P., and Byerlee D. (2009) Awakening Africa's Sleeping Giant: Prospects for Commercial Agriculture in the Guinea Savannah Zone and Beyond, The World
Bank, Washington DC. http://dx.doi.org/10.1596/978-0-8213-7941 $-7$

Mueller, N.D., Gerber, J.S., Johnston, M., Ray, D.K., Ramankutty, N., and Foley, J.A. (2012). Closing yield gaps through nutrient and water management. Nature, 490, 254-257. http://dx.doi.org/10.10 38/nature 11420

New, M., Lister, D., Hulme, M., and Makin, I. (2002). A highresolution data set of surface climate over global land areas. Clim. Res., 21(1), 1-25. http://dx.doi.org/10.3354/cr021001

Nicklow, J., Reed, P., Savic, D., Dessalegne, T., Harrell, L., Chan-Hilton, A., Karamouz, M., Minsker, B., Ostfeld, A., Singh, A., and Zechman, E. (2010). State of the art for genetic algorithms and beyond in water resources planning and management. $J$. Water Resour. Plann. Manage., 136(4), 412-432. http://dx.doi.org/10.10 61/(ASCE)WR.1943-5452.0000053

Panagopoulos, Y., Makropoulos, C., and Mimikou, M. (2012). Decision support for diffuse pollution management. Environ. Model. Software, 30, 57-70. http://dx.doi.org/10.1016/j.envsoft.2011.11.0 06

Panagopoulos, Y., Makropoulos, C., Kossida, M., and Mimikou, M. (2013). Optimal implementation of irrigation practices: Costeffective desertification action plan for the pinios basin. J. Water Resour. Plann. Manage., 140(10), 05014005. http://dx.doi.org/10. 1061/(ASCE)WR.1943-5452.0000428

Pandey, S., and Hardaker, J.B. (1995). The role of modelling in the quest for sustainable farming systems. Agric. Syst., 47(4), 439-450. http://dx.doi.org/10.1016/0308-521X(95)92109-J

Pastori, M., Bouraoui, F., Aloe, A., and Bidoglio, G. (2011). GISEPIC AFRICA: A Modeling Tool for Assessing Impacts of Nutrient and Water Use in African Agriculture -- JRC63230, Publications Office of the European Union, Luxembourg.

Pujol, J., Raggi, M., and Viaggi, D. (2006). The potential impact of markets for irrigation water in Italy and Spain: A comparison of two study areas. Aust. J. Agric. Resour. Econ., 50(3), 361-380. http://dx.doi.org/10.1111/j.1467-8489.2006.00352.x

Rabotyagov, S.S., Jha, M.K., and Campbell, T. (2010). Impact of crop rotations on optimal selection of conservation practices for water quality protection. J. Soil Water Conserv., 65(6), 369-380. http://dx.doi.org/10.2489/jswc.65.6.369

Recknagel, F. (2013). Current scope, case studies and future directions of ecological informatics. J. Environ. Inf., 21(1), 3-11. http:// dx.doi.org/10.3808/jei.201300227

Reed, P.M., Hadka, D., Herman, J.D., Kasprzyk, J.R., and Kollat, J.B. (2013). Evolutionary multiobjective optimization in water resources: The past, present, and future. Adv. Water Resour., 51, 438456. http://dx.doi.org/10.1016/j.advwatres.2012.01.005

Rinaldi, M. (2001). Application of EPIC model for irrigation scheduling of sunflower in Southern Italy. Agric. Water Manage., 49(3), 185-196. http://dx.doi.org/10.1016/S0378-3774(00)00148-7

Rizov, M. (2004). Rural development and welfare implications of CAP reforms. J. Policy Model., 26(2), 209-222. http://dx.doi.org/ 10.1016/j.jpolmod.2004.03.003

Romero, C., and Rehman, T. (2003). Multiple Criteria Analysis for Agricultural Decisions, Elsevier Science Publishers.

Rosegrant, M.W., and Cline, S.A. (2003). Global food security: Challenges and policies. Science, 302(5652), 1917-1919. http://dx.doi. org/10.1126/science. 1092958

Sadeghi, S.H.R., Jalili, K., and Nikkami, D. (2009). Land use optimization in watershed scale. Land Use Policy, 26(2), 186-193. http://dx.doi.org/10.1016/j.landusepol.2008.02.007

Sall, M., and Vanclooster, M. (2009). Assessing the well water pollution problem by nitrates in the small scale farming systems of the Niayes region, Senegal. Agric. Water Manage., 96(9), 13601368. http://dx.doi.org/10.1016/j.agwat.2009.04.010 
Sarker, R., and Ray, T. (2009). An improved evolutionary algorithm for solving multi-objective crop planning models. Comput. Electron. Agric., 68(2), 191-199. http://dx.doi.org/10.1016/j.compag.20 09.06.002

Schröter, D., Cramer, W., Leemans, R., Prentice, I.C., Araújo, M.B., Arnell, N.W., Bondeau, A., Bugmann, H., Carter, T.R., Gracia, C.A., de la Vega-Leinert, A.C., Erhard, M., Ewert, F., Glendining, M., House, J.I., Kankaanpää, S., Klein, R.J.T., Lavorel, S., Lindner, M., Metzger, M.J., Meyer, J., Mitchell, T.D., Reginster, I., Rounsevell, M., Sabaté, S., Sitch, S., Smith, B., Smith, J., Smith, P., Sykes, M.T., Thonicke, K., Thuiller, W., Tuck, G., Zaehle, S., and Zierl, B. (2005). Ecosystem service supply and vulnerability to global change in Europe. Science, 310(5752), 1333-1337. http: //dx.doi.org/10.1126/science.1115233

Sheffield, J., Goteti, G., and Wood, E.F. (2006). Development of a 50 -year high-resolution global dataset of meteorological forcings for land surface modeling. J. Climate, 19, 3088-3111. http://dx. doi.org/10.1175/JCLI3790.1

Sutton, M.A., Howard, C.M., Erisman, J.W., Billen, G., Bleeker, A., Grennfelt, P., van Grinsven, H., and Grizzetti, B. (2011). The European Nitrogen Assessment, Cambridge University Press. http: //dx.doi.org/10.1017/CBO9780511976988

The Montpellier Panel (2013). Sustainable Intensification: A New Paradigm for African Agriculture, Agriculture for Impact, Imperial College, London, UK.
Udías, A., Galbiati, L., Elorza, F.J., Efremov, R., Pons, J., and Borras, G. (2011). Framework for multi-criteria decision management in watershed restoration. J. Hydroinf., 14(2), 395-411. http://dx.doi. org/10.2166/hydro.2011.107

Van der Velde, M., Folberth, C., Balkovič, J., Ciais, P., Fritz, S., Janssens, I.A., Obersteiner, M., See, L., Skalský, R., Xiong, W., and Peñuelas, J. (2014). African crop yield reductions due to increasingly unbalanced Nitrogen and Phosphorus consumption. Global Change Biol., 20(4), 1278-1288. http://dx.doi.org/10.1111/ gcb. 12481

Waha, K., Huth, N., Carberry, P., and Wang, E. (2015). How model and input uncertainty impact maize yield simulations in West Africa. Environ. Res. Lett., 10(2), 024017. http://dx.doi.org/10.10 88/1748-9326/10/2/024017

Whittaker, G., Confesor Jr., R., Griffith, S.M., Färe, R., Grosskopf, S., Steiner, J.J., Mueller-Warrant, G.W., and Banowetz, G.M. (2009). A hybrid genetic algorithm for multiobjective problems with activity analysis-based local search. Eur. J. Oper. Res., 193(1), 195-203. http://dx.doi.org/10.1016/j.ejor.2007.10.050

Williams, J.R. (1995). The EPIC model, in V.P. Singh (Ed.), Computer Models of Watershed Hydrology, Water Resources Publications, Highlands Ranch, CO, USA.

Wriedt, G., Van der Velde, M., Aloe, A., and Bouraoui, F. (2009). Estimating irrigation water requirements in Europe. J. Hydrol., 373(3-4), 527-544. http://dx.doi.org/10.1016/j.jhydrol.2009.05.018 